\title{
Degree of Observance of Ease of Doing Business and Efficient Government Service Delivery Act in the Department of Education in Nueva Ecija in the Philippines
}

\author{
Mary Jane J. Romero \\ Department of Education Division of Nueva Ecija \\ E-mail: majaro2495@gmail.com
}

Marites A. De Guzman

Dr. Paulino J. Garcia Memorial Research and Medical Center

E-mail: justmatearts04@yahoo.com

\author{
Olive Chester Cuya-Antonio (Corresponding author) \\ Department of Public Administration, Nueva Ecija University of Science and \\ Technology \\ Gen. Tinio St., Quezon Dist., Cabanatuan City, Philippines \\ E-mail: olivechester.cuya27@gmail.com
}

Received: Jan. 20, 2019 Accepted: Feb. 26, 2019 Online published: Mar. 1, 2019

doi:10.5296/jpag.v9i1.14238

URL: https://doi.org/10.5296/jpag.v9i1.14238

\begin{abstract}
Implementation of laws intended to prevent commission of negative bureaucratic behavior is a challenge to most government agencies. Republic Act No. 11032, otherwise known as Ease of Doing Business and Efficient Government Service Delivery Act of 2018, aims to strengthen the Anti-Red Tape Act (ARTA) of 2007 that lessens the perennial problem of bureaucratic red tape which causes graft and corruption. This study aims to determine the degree of observance on the three core components of ARTA namely citizen's charter, access to government service through frontline services, and report card survey. In addition,
\end{abstract}


zero-contact policy is also observed which is an amendment to the existing law. Based on the results, the core components of Republic Act No. 11032 are always observed in the Department of Education Division of Nueva Ecija but the presence of queuing is observed regardless of the institution's effort to eliminate red tapes. The success of policy implementation can be fully achieved when coupled with a change of behavior on both part of the service providers and public clientele. Bureaucratic equity followed by inculcation of core values by the service providers with the embodiment of the norms of conduct and ethical standards contribute in the delivery of an efficient government service.

Keywords: ease of doing business, anti-red tape act, zero-contact policy, education, efficient government service delivery, policy implementation, Philippines

\section{Introduction}

The culture of graft and corruption is one of the factors that contributes to a spoil system in Philippine bureaucracy that restricts the efficiency of government services and assassinate the neutrality in politics (Caren, 2012). Despite the presence of law which criminalizes acts of bribery, extortion, abuse of office and conflict of interest, still, legislative framework is not adequate to improve service delivery (GAN, 2017).

The 2010 Annual Poverty Indicators Survey (APIS) conducted by the Philippines National Statistics Office in August 2010 revealed that 75 percent of families with at least one member is supply driven or voluntarily gave the money, gift or favor in exchange of ease in transaction, while the other 25 percent were demand-driven. Less than one percent of those who did not voluntarily give pecuniary reported the incident (Hays, 2018).

Local Government Units gained the highest corruption related complaints for seven consecutive years based on the report released by the ombudsman's Finance and Management Information Office (FMIO). A total of 3,189 complaints was filed against local government unit officials for the year 2017 followed by 939 complaints against the Philippine National Police (PNP), 310 to the officials of Department of Education, 184 of Department of Environment and Natural Resources and 117 complaints against officials of state universities and colleges. All the complaints filed with the employees of the said agencies were criminal and administrative in nature (Antiporda, 2018).

Government agencies were described as inefficient, inaccessible and unresponsive even though they have higher compensation with less responsibility compared to private sector. The present administration tries to stop this dilemma through strengthening the results accountability in carrying out government programs for the delivery of effective services. Results-Based Performance Management System (RBPMS) is one of the initiatives of the government to unify the systems and incorporate the metrics on performance excellence in meeting citizen's satisfaction and efficient internal processes. It also determines the entitlements of agencies and employees on rewards and incentives. The Performance-Based Incentive System (PBIS) is adopted in 2012 to recognize an exemplary accomplishment of high participating agencies in achieving their commitments. It increases their compliance to governance standards including the existing laws and regulations like the Anti-Red Tape 
program. PBIS developed the understanding of government officials regarding their respective roles and mandates that bring improvements in the quality of performance indicators and management practices with good governance conditions (DAP, 2018).

Republic Act No. 11032 otherwise known as Ease of Doing Business and Efficient Government Service Delivery Act of 2018 signed by President Rodrigo R. Duterte on May 18, 2018 amending the purpose of Anti-Red Tape Act of 2007aims to lessen the perennial problem of bureaucratic red tapes that causes graft and corruption by re-engineering systems, simplifying requirements and procedures to improve the turnaround processing time. It generally promotes transparency and accountability both business and non-business transaction in the delivery of government service.

Transparency is a tool that increases accountability. It disinfects the inefficient and corrupt practices in the government (Gabriel 2018). After all, the public clientele has the right to demand for quality and prompt service from its supply side which is the government. Citizen engagement is a must to exert pressure to those service providers and control corruption which is considered as a critical dimension of government reform (Brillantes \& Fernandez 2011).

Previously, Anti-Red Tape Act (ARTA) of 2007 establishes effective practices that prevents and penalize graft and corruption practices in the government that will apply in all government offices and agencies. Administrative Order No. 241 dated October 2, 2008 mandates the speedy implementation of this act with its implementing rules and regulations. As a national government agency, Department of Education (DepEd) disseminates this act through DepEd Memorandum No. 502 s. 2008 and reiterating its compliance under DepEd Order No. 37, s. 2013 that all offices from national to the school level is directed to have Public Assistance Desk (PAD) that is accessible and situated at the most conspicuous area. Citizen's Charter must be posted on PAD area that clearly contains the step-by-step procedure, officer responsible, fees, documents and time needed to obtain a particular service. Also, compliance report must be submitted to prove its implementation.

According to Gabriel (2018), there are three core components of ARTA namely, (1) Citizen's Charter that is the bench mark of performance to know the standard of service that the clients can demand to their service providers; (2) Frontline Services where the public can access the government service and (3) Report Card Survey (RCS) which serves as a feedback mechanism that measures the quality of service of the agency. These three core components of ARTA were also present in the amended law.

In addition, RA 11032 promotes Zero-Contact Policy between the government employees and clients except preliminary assessment of request and the evaluation of the complacency of the requirements submitted or unless it is strictly necessary. This widens the scope of frontline services that primarily receives the requests and documents of the public clientele. This attempts to reduce red-tapes since the processor has no direct contact to the clients. Also, RA 11032 reduces the processing time which shall not be longer than 3 working days in simple transactions, 7 working days in complex transactions and 20 working days in the applications that may endanger the public health, safety, morals, policy and highly technical transactions. 
The maximum time prescribed can be extended only once with the same number prescribed in the $\mathrm{CC}$ provided that the agency will provide written notification signed by its client of the reason on the delay of service. This attempt of the government aims to improve the ranking of the Philippines as it experiences its worst decline among countries in Asia-Pacific, ranked 113 out of 160 countries in Doing Business Report (World Bank, 2018).

Upon approval, ease of doing business is now on implementation stage along with the efficient delivery of government service that was previously enacted by the amended law. Previous study of Gabriel (2018) shows that there is a high degree of observance of ARTA's three core components in the ten municipalities of Nueva Ecija verbally described as almost always to always however, the presence of fixers and additional fees for the ease of transaction were present and seldom observed. Republic Act No. 6713 otherwise known as Code of Conduct and Ethical Standards for Public Officials and Employees promotes high ethics standard in public service, prohibiting unrighteous acts and transactions including acceptance of gifts or any monetary rewards in the performance of duty. This bureaucratic red tapes creates a negative impression on the efficiency and effectiveness of the operation of the democratic state (Gabriel 2017). After all, reforms in processes and procedures in the delivery of government service will be ineffective if it is not accompanied by reforms of values, mindsets and behaviors of the public servants (Brillantes \& Fernandez 2011).

This study aims to determine the degree of observance of the provision of Ease of Doing Business and Efficient Delivery of Government Service in the Department of Education-Division of Nueva Ecija (DepEd-NE). Specifically, this study determines the degree of observance of DepEd-NE of the following: (1) Citizen's Charter Provisions; (2) Access to Government Services through Frontline Services; (3) Report Card Survey; (4) Zero-Contact Policy and (5) to provide recommendations for the improvement of policy implementation.

\section{Methodology}

DepEd-NE was categorized in four Congressional Districts (CD) based on the present categorization of the division. The biggest and the largest numbers of clientele came from CD I consisting of nine municipalities namely: Aliaga, Licab, Cuyapo, Guimba, Nampicuan, Quezon, Sto, Domingo, Talavera and Zaragoza. The smallest CD is the second district with six municipalities: Carranglan, Llanera, Lupao, Pantabangan, Rizal and Talugtug. CD III consists of six municipalities, these are Bongabon, Gen. Natividad, Laur, Gabaldon, Palayan and Sta. Rosa with one school at Cabanatuan City which is the Nueva Ecija High School. And the last district consists of seven municipalities; Cabio, San Antonio, Gen. Tinio, San Isidro, Penaranda, Jaen and San Leonardo. Schools under the division of Gapan, Munoz, San Jose and Cabanatuan were not included in this study.

The participants of the study were identified using convenient random sampling. Twenty-five participants were chosen on each congressional district to fairly represent the different groups with a total of one hundred employees. The participants can be described based on their position, sex, civil status and highest educational attainment. 
The study used questionnaires with 5 point Likert's scale as the main instrument constructed based on the provisions of RA 11032 and will be validated by interviews and observations. The survey was conducted in ten working days from November 19 to November 30, 2018. Weighted mean and analysis of variance (ANOVA) are the statistical treatment used to determine if there is a significant difference between the observance of different congressional districts of DepEd-NE

\section{Results and Discussion}

The following tables show the result on the degree of observance on the core components of RA 11032 on the four different congressional districts in DepEd-NE.

\subsection{Citizen's Charter Provisions}

Table 1. Citizen's Charter Provisions

\begin{tabular}{|c|c|c|c|c|c|c|c|}
\hline \multirow{2}{*}{\multicolumn{2}{|c|}{$\begin{array}{c}\text { Citizen's Charter } \\
\text { Situations }\end{array}$}} & \multirow{2}{*}{$\begin{array}{ll}\mathrm{CD} I \\
\mathrm{WM} \\
\end{array}$} & \multirow{2}{*}{$\begin{array}{l}\mathrm{CD} \text { II } \\
\mathrm{WM} \\
\end{array}$} & \multirow{2}{*}{$\begin{array}{ll}\text { CD III } \\
\text { WM } \\
\end{array}$} & \multirow{2}{*}{$\begin{array}{l}\text { CD IV } \\
\text { WM } \\
\end{array}$} & \multicolumn{2}{|c|}{ Overall } \\
\hline & & & & & & WM & VD \\
\hline 1 & $\begin{array}{l}\text { CC is posted at the main entrance of offices } \\
\text { or at the most conspicuous place. }\end{array}$ & 4.40 & 4.72 & 4.68 & 4.68 & 4.62 & A \\
\hline 2 & $\begin{array}{l}\mathrm{CC} \text { is posted at the website of the division } \\
\text { office }\end{array}$ & 4.12 & 4.76 & 4.52 & 4.6 & 4.5 & A \\
\hline 3 & $\begin{array}{l}\mathrm{CC} \text { is posted in the form of published } \\
\text { materials written either English or Filipino }\end{array}$ & 4.12 & 4.72 & 4.52 & 4.4 & 4.44 & A \\
\hline 4 & CC contains the vision of the institution. & 4.76 & 4.76 & 4.72 & 4.76 & 4.75 & $\mathrm{~A}$ \\
\hline 5 & CC contains the mission of the institution. & 4.68 & 4.8 & 4.72 & 4.76 & 4.74 & $\mathrm{~A}$ \\
\hline 6 & CC contains the objectives of the institution. & 4.72 & 4.76 & 4.64 & 4.76 & 4.72 & A \\
\hline 7 & $\begin{array}{l}\text { CC contains the core values of the } \\
\text { institution. }\end{array}$ & 4.64 & 4.8 & 4.68 & 4.68 & 4.7 & A \\
\hline 8 & $\begin{array}{l}\mathrm{CC} \text { enumerates the comprehensive checklist } \\
\text { of requirements needed for each type of } \\
\text { request. }\end{array}$ & 4.48 & 4.6 & 4.48 & 4.36 & 4.48 & A \\
\hline 9 & $\begin{array}{l}\text { CC enumerates the uniform checklist of } \\
\text { requirements needed for each type of } \\
\text { request. }\end{array}$ & 4.52 & 4.6 & 4.52 & 4.44 & 4.52 & A \\
\hline 10 & $\begin{array}{l}\text { CC enumerates the step-by-step procedure to } \\
\text { obtain a particular service. }\end{array}$ & 4.52 & 4.6 & 4.6 & 4.44 & 4.54 & A \\
\hline 11 & $\begin{array}{l}\text { CC determines the person responsible at } \\
\text { each step. }\end{array}$ & 4.48 & 4.64 & 4.56 & 4.48 & 4.54 & A \\
\hline 12 & $\begin{array}{l}\text { CC determine the maximum time to } \\
\text { conclude the process }\end{array}$ & 4.4 & 4.48 & 4.56 & 4.44 & 4.47 & A \\
\hline 13 & $\begin{array}{l}\text { CC enumerates the documents to be } \\
\text { presented by the requesting party if } \\
\text { necessary. }\end{array}$ & 4.44 & 4.52 & 4.52 & 4.48 & 4.49 & A \\
\hline 14 & $\begin{array}{l}\text { CC determines the amount if fees needed if } \\
\text { necessary. }\end{array}$ & 4.28 & 4.52 & 4.6 & 4.36 & 4.44 & A \\
\hline 15 & $\begin{array}{l}\text { CC determines the procedure of filing a } \\
\text { complaint. }\end{array}$ & 4.36 & 4.48 & 4.44 & 4.44 & 4.43 & A \\
\hline & Overall Weighted Mean & 4.46 & 4.65 & 4.58 & 4.54 & 4.56 & A \\
\hline
\end{tabular}

Legend: 1.00 to 1.79 is Never $(\mathrm{N}) ; 1.80$ to 2.59 is Seldom (Se); 2.60 to 3.39 is Sometimes 
(So); 3.40 to 4.19 is Almost Always (AA); 4.20 to 5.00 is Always; VD is Verbal Description; WM is Weighted Mean.

The data on Table 1 shows that the highest degree of observance on the implementation of the provisions of citizen's charter is from CD II with an overall weighted mean of 4.65. It is followed by CD III, IV and I with overall weighted mean of 4.58, 4.56 and 4.46 respectively. All the results can be verbally described as always. From the results, it can be described that the provisions of citizen's charter are implemented and can visibly observed within the institution.

It can be observed that the institution uses electronic means in posting their citizen's charter that is conspicuously visible by the public clientele as it was located in the receiving area where front liners are located. The CC that contains the mission, vision, objectives and core values of the institution is being flashed in the television. It also enumerates the step-by-step procedure, person responsible, documents to be presented and the maximum time to be concluded on each transaction. The posting of Citizens Charter on conspicuous place in government agency is compliance to transparency requirement in government operation. Transparency is important in government operation as it is observed that it is correlated to practice and performance (Gabriel and Gutierrez, 2017). Transparency is embraced by accountability. It ensures higher local legislative performance commensurate to the value of public money (Gabriel and Ong 2018). Posting of citizens charter informs the public of the standard of service so that they may demand for it.

Although there is a comprehensive and uniform checklist on each type of transaction, one of the participant from CD I suggested that if possible, minimize the requirements on the checklist which is not possible as the concern of the processor because it was already lessen and based on what the process requires especially on the transactions that involves appointments.

Table 2. Result of ANOVA on the Citizen's Charter

\begin{tabular}{l|c|c|c|c|c}
\hline ANOVA & Sum of Squares & Df & Mean Square & F & Sig. \\
\hline Between Groups & .285 & 3 & .095 & 4.639 & .006 \\
\hline Within Groups & 1.146 & 56 & .020 & & \\
\hline Total & 1.430 & 59 & & & \\
\hline
\end{tabular}

The mean difference is significant at the 0.01 level

The table shows the difference in the degree of observance on different congressional districts in DepEd-NE in terms of the implementation of the citizen's charter provisions. The analysis revealed that there is significant difference on their observation at significance level of less than 0.01 . Thus, post hoc analysis must be done to identify exactly the congressional districts showing the difference in their observance. 
Table 3. Post Hoc Analysis of Citizen's Charter using Scheffe's Test

\begin{tabular}{c|c|c|c}
\hline \multicolumn{2}{c|}{ Congressional Districts (Scheffe) } & Mean Difference & Sig. \\
\hline \multirow{2}{*}{ CD I } & CD II & $-.18933^{*}$ & .008 \\
\cline { 2 - 4 } & CD III & -.12267 & .151 \\
\cline { 2 - 4 } & CD IV & -.07733 & .538 \\
\hline \multirow{2}{*}{ CD II } & CD III & .06667 & .655 \\
\cline { 2 - 4 } & CD IV & .11200 & .216 \\
\hline \multirow{2}{*}{ CD III } & CD IV & .04533 & .860 \\
\hline
\end{tabular}

*the mean difference is significant at the 0.05 level.

By using the Scheffe's test, analysis of the difference between the observance of the four CD's were determined. The data on Table 3 shows the sources of difference of the answers of the participants with the same question. When the observance of CD I is matched with CD II, the mean difference is -.18933 and the significant level is 0.05 . When it is matched to CD IV, the observance of the provisions on Citizen's Charter shows -.07733. The degree of observance of CD I is different from the degree of observance of CD II and CD IV; CD II and IV and CD III and CD IV regarding the implementation of the citizen's charter provisions at Department of Education Division of Nueva Ecija.

\subsection{Access to Government Service through Frontline Services}

Table 4. Access to Government Service through Frontline Services

\begin{tabular}{l|l|l|l|l|l|l|l}
\hline $\begin{array}{l}\text { Access to Government Service through } \\
\text { Frontline Services }\end{array}$ & CD I & CD II & CD III & \multicolumn{2}{|c|}{ CD IV } & \multicolumn{2}{|c}{ Overall } \\
\hline Situations & WM & WM & WM & WM & WM & VD \\
\hline 1 & $\begin{array}{l}\text { The employees accept written request } \\
\text { of the requesting party. }\end{array}$ & 4.48 & 4.48 & 4.76 & 4.6 & 4.58 & A \\
\hline 2 & $\begin{array}{l}\text { The receiving officer perform } \\
\text { preliminary assessment of the request } \\
\text { to ensure more expeditious action. }\end{array}$ & 4.6 & 4.4 & 4.68 & 4.48 & 4.54 & A \\
\hline 3 & $\begin{array}{l}\text { The receiving officer assign a unique } \\
\text { identification number on each } \\
\text { request. }\end{array}$ & 4.24 & 4.48 & 4.68 & 4.48 & 4.47 & A \\
\hline 4 & $\begin{array}{l}\text { The receiving officer issue } \\
\text { acknowledgement receipt to the } \\
\text { request }\end{array}$ & 4.32 & 4.56 & 4.76 & 4.56 & 4.55 & A \\
\hline 5 & $\begin{array}{l}\text { All request submitted are acted upon } \\
\text { the assigned officer within the } \\
\text { prescribed processing time in the CC. }\end{array}$ & 4.24 & 4.44 & 4.52 & 4.4 & 4.40 & A \\
\hline 6 & $\begin{array}{l}\text { The processing time prescribed by } \\
\text { the CC is not longer than 3 working } \\
\text { days for simple transactions. }\end{array}$ & 4.52 & 4.44 & 4.68 & 4.56 & 4.55 & A \\
\hline
\end{tabular}




\begin{tabular}{|c|c|c|c|c|c|c|c|}
\hline 7 & $\begin{array}{l}\text { The processing time prescribed by } \\
\text { the } \mathrm{CC} \text { is not longer than } 7 \text { working } \\
\text { days for complex transactions. }\end{array}$ & 4.52 & 4.44 & 4.6 & 4.16 & 4.43 & A \\
\hline 8 & $\begin{array}{l}\text { The processing time for highly } \\
\text { technical transactions is not longer } \\
\text { than } 20 \text { working days. }\end{array}$ & 4.36 & 4.4 & 4.44 & 4.08 & 4.32 & A \\
\hline 9 & $\begin{array}{l}\text { The maximum time prescribed is } \\
\text { extended only once for the same } \\
\text { number of days prescribed in the CC. }\end{array}$ & 4.24 & 4.52 & 4.52 & 4.28 & 4.39 & A \\
\hline 10 & $\begin{array}{l}\text { The institution or the concerned unit } \\
\text { issue a written notification prior to } \\
\text { the lapse of processing time. }\end{array}$ & 4.08 & 4.4 & 4.56 & 4.44 & 4.37 & A \\
\hline 11 & $\begin{array}{l}\text { The written notification include the } \\
\text { reason of extension and the final date } \\
\text { of release of a particular request. }\end{array}$ & 4.28 & 4.4 & 4.28 & 4.44 & 4.35 & A \\
\hline 12 & $\begin{array}{l}\text { The notification bears the signature } \\
\text { of the requesting party that serve as } \\
\text { proof of notice. }\end{array}$ & 4.2 & 4.36 & 4.36 & 4.16 & 4.27 & A \\
\hline 13 & $\begin{array}{l}\text { No request is being returned to the } \\
\text { requesting party without appropriate } \\
\text { action. }\end{array}$ & 4.72 & 4.44 & 4.52 & 4.52 & 4.55 & A \\
\hline 14 & $\begin{array}{l}\text { Formal notice is being issued on } \\
\text { disapproved request. }\end{array}$ & 4.16 & 4.4 & 4.36 & 4.64 & 4.39 & A \\
\hline 15 & $\begin{array}{l}\text { Formal notice for disapproved } \\
\text { request clearly indicates the reason of } \\
\text { disapproval. }\end{array}$ & 4.56 & 4.44 & 4.44 & 4.4 & 4.46 & A \\
\hline 16 & $\begin{array}{l}\text { Denial of request is fully explained } \\
\text { into writing. }\end{array}$ & 4.6 & 4.44 & 4.48 & 4.68 & 4.55 & A \\
\hline 17 & $\begin{array}{l}\text { Denial of request states the name of } \\
\text { the person making the denial. }\end{array}$ & 4.4 & 4.44 & 4.36 & 4.44 & 4.41 & A \\
\hline 18 & $\begin{array}{l}\text { Denial of request states the reason for } \\
\text { denial. }\end{array}$ & 4.28 & 4.32 & 4.36 & 4.56 & 4.38 & A \\
\hline 19 & $\begin{array}{l}\text { Signatories in any documents are } \\
\text { limited on three (3) signatures. }\end{array}$ & 4.36 & 4.4 & 4.4 & 4.64 & 4.45 & A \\
\hline 20 & $\begin{array}{l}\text { There is an alternate signatory if the } \\
\text { authorized signatory is on official } \\
\text { business. }\end{array}$ & 4.36 & 4.44 & 4.64 & 4.52 & 4.49 & A \\
\hline 21 & $\begin{array}{l}\text { The institution uses electronic } \\
\text { version of clearances, permits, } \\
\text { certifications or authorizations that } \\
\text { can be printed by the requesting party } \\
\text { with the same level of authority as to } \\
\text { the signed hard copy. }\end{array}$ & 4.32 & 4.28 & 4.48 & 4.64 & 4.43 & A \\
\hline
\end{tabular}




\begin{tabular}{c|l|r|r|r|r|r|c}
\hline 22 & $\begin{array}{l}\text { The offices are attended at all times } \\
\text { even during lunch break. }\end{array}$ & 4.48 & 4.56 & 4.68 & 4.6 & 4.58 & $\mathrm{~A}$ \\
\hline 23 & $\begin{array}{l}\text { Employees are wearing their } \\
\text { identification card. }\end{array}$ & 4.52 & 4.56 & 4.64 & 4.6 & 4.58 & $\mathrm{~A}$ \\
\hline 24 & $\begin{array}{l}\text { There is an established Public } \\
\text { Assistance/Complaint Desk within } \\
\text { the institution. }\end{array}$ & 4.64 & 4.52 & 4.68 & 4.72 & 4.64 & $\mathrm{~A}$ \\
\hline
\end{tabular}

Legend: 1.00 to 1.79 is Never $(\mathrm{N}) ; 1.80$ to 2.59 is Seldom $(\mathrm{Se}) ; 2.60$ to 3.39 is Sometimes (So); 3.40 to 4.19 is Almost Always (AA); 4.20 to 5.00 is Always; VD is Verbal Description; WM is Weighted Mean.

The table shows that the frontline services clearly follow the standard in providing an efficient government service, as the highest degree of observance is 4.54 from CD II and the lowest is 4.40 , all can be verbally described as always.

The division has records section that is primarily responsible in receiving the request of the clients. They are the one who forwards it to the concerned office especially in complex transactions that is more than three working days. In case of simple transactions, the frontline services facilitate the transaction immediately. Each office has a representative in each PAD where the clients can transact. Frontline services of the division are similar to a bank with a queuing system to have a systematic approach in dealing with their clients and it was attended at all times even lunch break. Clearly, public personnel affect the quality of service that the government provides to the public (Tumampus et. Al, 2018).

Table 5. Result of ANOVA on Access to Government Service through Frontline Services.

\begin{tabular}{l|c|c|c|c|c}
\hline ANOVA & Sum of Squares & df & Mean Square & F & Sig. \\
\hline Between Groups & .264 & 3 & .088 & 4.291 & .007 \\
\hline Within Groups & 1.885 & 92 & .020 & & \\
\hline Total & 2.149 & 95 & & & \\
\hline
\end{tabular}

The table shows that there is significant difference between the observation of the provision of frontline services between different districts and it can be determined using a post hoc analysis as shown in table 6 .

Table 6. Post Hoc Analysis of Access to Government Service through Frontline Services using Scheffe's Test.

\begin{tabular}{c|c|c|c}
\hline \multicolumn{2}{c|}{ Congressional Districts (Scheffe) } & Mean Difference & Sig. \\
\hline \multirow{4}{*}{ CD I } & CD II & -.04500 & .757 \\
\cline { 2 - 4 } & CD III & $-.14167^{*}$ & .011 \\
\cline { 2 - 4 } & CD IV & -.08833 & .214 \\
\hline \multirow{4}{*}{ CD II } & CD III & -.09667 & .148 \\
\cline { 2 - 4 } & CD IV & -.04333 & .777 \\
\hline CD III & CD IV & .05333 & .646 \\
\hline
\end{tabular}


Legend: * the mean difference is significant at 0.05 level.

The table shows that when the observation of CD I is matched to CD II the mean difference is -.04500 , when it is matched to CD III the mean difference is -.14167 at significance level of 0.05 and when it is matched to CD IV the result is -.08833. The table shows the divergence between the answers of the participants in the access of government service at DepEd-NE in terms of frontline services.

\subsection{Report Card Survey}

Table 7. Report Card Survey

\begin{tabular}{|c|c|c|c|c|c|c|c|}
\hline \multirow{2}{*}{\multicolumn{2}{|c|}{$\frac{\text { Report Card Survey }}{\text { Situations }}$}} & \multirow{3}{*}{$\begin{array}{l}\mathrm{CD} I \\
\mathrm{WM} \\
4.52\end{array}$} & \multirow{3}{*}{$\begin{array}{c}\frac{C D}{\text { II }} \\
\text { WM } \\
4.64\end{array}$} & \multirow{3}{*}{\begin{tabular}{|c|} 
CD III \\
WM \\
4.76
\end{tabular}} & \multirow{3}{*}{$\begin{array}{c}\text { CD IV } \\
\text { WM } \\
4.6\end{array}$} & \multicolumn{2}{|c|}{ Overall } \\
\hline & & & & & & \multirow{2}{*}{$\frac{\mathrm{WM}}{4.58}$} & \multirow{2}{*}{ VD } \\
\hline 1 & $\begin{array}{l}\text { The Citizen's Charter (CC) contains service } \\
\text { commitments on transaction steps. }\end{array}$ & & & & & & \\
\hline 2 & $\begin{array}{l}\text { The CC contains the cost that can be } \\
\text { incurred at each services of the institution. }\end{array}$ & 4.44 & 4.6 & 4.68 & 4.48 & 4.54 & A \\
\hline 3 & $\begin{array}{l}\text { The CC contains the time to be concluded } \\
\text { in each step of the institution's services }\end{array}$ & 4.52 & 4.52 & 4.68 & 4.48 & 4.47 & A \\
\hline 4 & $\begin{array}{l}\text { There is hidden cost that charges to the } \\
\text { requesting party. }\end{array}$ & 2.84 & 2.64 & 4.76 & 4.56 & 4.55 & A \\
\hline 5 & $\begin{array}{l}\text { There is an existing anti-fixing campaign } \\
\text { located in the vicinity. }\end{array}$ & 4.4 & 4.08 & 4.52 & 4.4 & 4.40 & A \\
\hline 6 & There is anti-red tape campaign poster. & 4.32 & 4.16 & 4.68 & 4.56 & 4.55 & A \\
\hline 7 & There is fixer in the institution. & 3.36 & 2.72 & 4.6 & 4.16 & 4.43 & A \\
\hline 8 & $\begin{array}{l}\text { There is an individual offering to facilitate } \\
\text { transaction in exchange of money. }\end{array}$ & 2.56 & 2.4 & 4.44 & 4.08 & 4.32 & A \\
\hline 9 & No noon break policy is observed. & 4.36 & 4.48 & 4.52 & 4.28 & 4.39 & A \\
\hline 10 & $\begin{array}{l}\text { There is public assistance and complaint } \\
\text { desk. }\end{array}$ & 4.6 & 4.72 & 4.56 & 4.44 & 4.37 & A \\
\hline 11 & $\begin{array}{l}\text { The employees wear their identification } \\
\text { cards. }\end{array}$ & 4.6 & 4.76 & 4.28 & 4.44 & 4.35 & A \\
\hline 12 & Quality is observed in the frontline services. & 4.64 & 4.52 & 4.36 & 4.16 & 4.27 & A \\
\hline 13 & There is a visitor's logbook. & 4.72 & 4.76 & 4.52 & 4.52 & 4.55 & A \\
\hline 14 & There is an issuance of visitors pass. & 4.72 & 4.8 & 4.36 & 4.64 & 4.39 & A \\
\hline 15 & $\begin{array}{l}\text { The frontline service providers act in a } \\
\text { timely and prompt manner. }\end{array}$ & 4.64 & 4.56 & 4.44 & 4.4 & 4.46 & A \\
\hline 16 & $\begin{array}{l}\text { The frontline service providers are } \\
\text { knowledgeable to the services that the } \\
\text { institution offers. }\end{array}$ & 4.6 & 4.56 & 4.48 & 4.68 & 4.55 & A \\
\hline 17 & $\begin{array}{l}\text { The frontline service providers are } \\
\text { competent. }\end{array}$ & 4.56 & 4.6 & 4.36 & 4.44 & 4.41 & A \\
\hline
\end{tabular}




\section{Macrothink}

Journal of Public Administration and Governance

ISSN 2161-7104

2019, Vol. 9, No. 1

\begin{tabular}{l|l|l|l|l|l|l|l}
18 & $\begin{array}{l}\text { The frontline service providers are } \\
\text { courteous. }\end{array}$ & 4.52 & 4.48 & 4.36 & 4.56 & 4.38 & $\mathrm{~A}$ \\
\hline 19 & $\begin{array}{l}\text { The frontline service providers assists the } \\
\text { requesting party even beyond working } \\
\text { hours }\end{array}$ & 4.32 & 4.52 & 4.4 & 4.64 & 4.45 & $\mathrm{~A}$ \\
\hline 20 & $\begin{array}{l}\text { The frontline service providers treat their } \\
\text { public clientele in an ethical manner. }\end{array}$ & 4.52 & 4.52 & 4.64 & 4.52 & 4.49 & $\mathrm{~A}$ \\
\hline 21 & $\begin{array}{l}\text { The frontline service providers displays } \\
\text { fairness. }\end{array}$ & 4.44 & 4.52 & 4.48 & 4.64 & 4.43 & $\mathrm{~A}$ \\
\hline 22 & $\begin{array}{l}\text { Quality is observed in the overall } \\
\text { transaction time. }\end{array}$ & 4.64 & 4.48 & 4.68 & 4.6 & 4.58 & $\mathrm{~A}$ \\
\hline 23 & $\begin{array}{l}\text { Quality is observed in the outcome of the } \\
\text { sevices offered by the institution. }\end{array}$ & 4.52 & 4.48 & 4.64 & 4.6 & 4.58 & $\mathrm{~A}$ \\
\hline 24 & $\begin{array}{l}\text { The physical setup of the institution is } \\
\text { comfortable. }\end{array}$ & 4.64 & 4.56 & 4.68 & 4.72 & 4.64 & $\mathrm{~A}$ \\
\hline 25 & $\begin{array}{l}\text { The physical setup of the institution is } \\
\text { conducive. }\end{array}$ & 4.56 & 4.56 & 4.64 & 4.52 & 4.57 & $\mathrm{~A}$ \\
\hline 26 & $\begin{array}{l}\text { The requesting party is satisfied on the } \\
\text { services that the institution provides. }\end{array}$ & 4.56 & 4.48 & 4.68 & 4.56 & 4.57 & $\mathrm{~A}$ \\
\hline
\end{tabular}

Legend: 1.00 to 1.79 is Never $(\mathrm{N}) ; 1.80$ to 2.59 is Seldom (Se); 2.60 to 3.39 is Sometimes (So); 3.40 to 4.19 is Almost Always (AA); 4.20 to 5.00 is Always; VD is Verbal Description; WM is Weighted Mean.

Report card survey quantifies the perceptions of the public clientele in terms of the efficiency, adequacy and quality of the institution's services. Its main objective is to obtain feedback on how the institutions comply on the provisions of their citizen's charter. It gives an idea on the amount of hidden charges, if any, incurred by public clientele in accessing government services through frontline services. Also, it aims to rate the institution's performance and overall client's satisfaction (CSC, 2014).

The table shows that DepEd-NE has an "always" overall degree of observance in the report card survey's core areas and sub-areas with the highest degree of observance of 4.43 from CD III. It can also always be observed at other districts with 4.36 and 4.35 at CD IV and I. The lowest degree of observance is from CD II with an overall weighted mean of 4.31 .

The first core area includes the compliance of the institution in ARTA Provisions which are the citizen's charter, anti-fixing campaign, no noon break policy, use of IDs and nameplates, presence of public assistance and complaint desk and the transaction must no hidden cost. The institution has an always degree of observance on the sub areas of the first core area except the last one. Seldom times, there is hidden costs that charges to the requesting party.

All the sub-areas on the second core area which is the overall client satisfaction to frontline service providers, service quality, physical setup and basic facilities of the institution has an 


\section{Macrothink}

Journal of Public Administration and Governance

ISSN 2161-7104

2019, Vol. 9, No. 1

always degree of observance among different districts. It can clearly conclude that DepEd-NE is performing well in terms of measuring their performance. However, it can be sometimes observed the presence of fixer within the institution. At seldom times, there is an individual offering to facilitate transaction in exchange of monetary gains even though there is an existing anti-fixer campaign and anti-red tape posters located and posted within the vicinity.

Table 8. Result of ANOVA on Report Card Survey

\begin{tabular}{l|c|c|c|c|c}
\hline \multicolumn{1}{c|}{ ANOVA } & Sum of Squares & Df & Mean Square & F & Sig. \\
\hline Between Groups & .227 & 3 & .076 & .147 & .932 \\
\hline Within Groups & 51.534 & 100 & .515 & & \\
\hline Total & 51.760 & 103 & & & \\
\hline
\end{tabular}

The table shows that there is no significant difference between the degree of observance of different congressional districts on the core areas of report card survey. Thus, there is no need for consequent analysis.

\subsection{Zero Contact Policy}

Table 9. Zero Contact Policy

\begin{tabular}{l|l|l|l|l|l|l|l}
\hline Zero Contact Policy & CD I & $\begin{array}{c}\text { CD } \\
\text { II }\end{array}$ & $\begin{array}{c}\text { CD } \\
\text { III }\end{array}$ & $\begin{array}{c}\text { CD } \\
\text { IV }\end{array}$ & \multicolumn{2}{|c}{ Overall } \\
\hline Situations & WM & WM & WM & WM & WM & VD \\
\hline 1 & $\begin{array}{l}\text { Zero contact policy is implemented in the } \\
\text { institution. }\end{array}$ & 4.08 & 4.24 & 4.24 & 4.12 & 4.17 & AA \\
\hline 2 & $\begin{array}{l}\text { Zero contact policy is observed in the } \\
\text { institution. }\end{array}$ & 4.24 & 4.2 & 4.16 & 4.08 & 4.17 & AA \\
\hline 3 & $\begin{array}{l}\text { The processor has no direct contact to the } \\
\text { requesting party. }\end{array}$ & 4 & 4.12 & 4.08 & 4.16 & 4.09 & AA \\
\hline 4 & $\begin{array}{l}\text { Preliminary assessment of the request and } \\
\text { evaluation of the sufficiency is the only } \\
\text { time where direct contact can be } \\
\text { observed. }\end{array}$ & 4.36 & 4.2 & 4.28 & 4.12 & 4.24 & A \\
\hline 5 & $\begin{array}{l}\text { The institution is presently using a system } \\
\text { to ease their transaction. }\end{array}$ & 4.68 & 4.24 & 4.52 & 4.2 & 4.41 & A \\
\hline \multicolumn{2}{l}{ Overall Weighted Mean } & 4.27 & 4.20 & 4.26 & 4.14 & 4.22 & A \\
\hline
\end{tabular}

Legend: 1.00 to 1.79 is Never $(\mathrm{N}) ; 1.80$ to 2.59 is Seldom (Se); 2.60 to 3.39 is Sometimes (So); 3.40 to 4.19 is Almost Always (AA); 4.20 to 5.00 is Always; VD is Verbal Description; WM is Weighted Mean.

The table shows that the provisions of zero contact policy can be overall concluded that it was always be observed at all the CD of DepEd-NE. The highest degree of observance is 4.27 from CD I followed by 4.26, 4.22 and 4.20 from CD III, IV and II respectively. It can always be observed that preliminary assessment of the request and evaluation is the only time where direct contact can be observed between the processor and the requesting party. Also, the 
institution is currently using a system that will eased the transactions. The aim of zero contact policy is to limit the direct interaction between the processors and public clientele that serves as a starting point of bureaucratic red tapes and corruption whenever they want to ease or shorten the transaction period.

Table 10. Result of ANOVA on Zero Contact Policy

\begin{tabular}{l|c|c|c|c|c}
\hline \multicolumn{1}{c|}{ ANOVA } & Sum of Squares & df & Mean Square & F & Sig. \\
\hline Between Groups & .057 & 3 & .019 & .733 & .548 \\
\hline Within Groups & .415 & 16 & .026 & & \\
\hline Total & .472 & 19 & & & \\
\hline
\end{tabular}

The result of ANOVA in Table10 shows that there is no significant difference in the degree of observance on the different districts in terms of the implementation of the policy and the use of post hoc analysis is not required.

\section{Conclusion and Recommendations}

Based on the results, it can be concluded that the core components of Republic Act No. 11032 otherwise known as Ease of Doing Business and Efficient Government Service Delivery Act which are the citizen's charter, access to government service through frontline services, report card survey and zero contact policy can always be observed in the Department of Education division of Nueva Ecija. The institution maximizes the use of technology to comply with the provisions of citizen's charter to promote transparency which correlates the quality of performance of the service providers, as well as, increase the awareness of the public clientele on the standard of government service. Hence, the public can demand to the government through the front line services. The overall degree of observance in the report card survey's core and sub-areas is a clear evidence in the quality, efficiency and adequacy of the institution's services together with their overall client's satisfaction. Regardless of the institution's effort to eliminate red tapes, the presence of fixers can sometimes be observed.

RA 11032 has a punitive mechanism to those individuals who commit violations enumerated under Section 21 that includes fixing or involvement to fixers in exchange of pecuniary gains. Also, penalties and liabilities are clearly stated under Section 22. It enumerates a precise punishment to the negative bureaucratic behavior, the problem is how the higher authority implements the law. Leadership is a critical role that initiates and sustains the transformation in government services (Calleja et al., 2016). Truly, the change in the government policies and laws can be fully implemented when there is a corresponding change in the behavior of both service providers and public clientele

The institution must have equity in the bureaucracy which is strictly implementing the law uniformly regardless of whom you know, avoiding nepotism and social connections just to avoid the penalty and liability in committing prohibited acts stated by the said law. The core values of the institution must be inculcated together with the norms of conduct stated in the code of conduct and ethical standards not only to the employees of DepEd-NE but also to all public officials who provides services to their public clientele. 


\section{Acknowledgement}

The researchers extend their gratitude to all those who supported, cooperated and contributed to complete this study. Thanks for Dr. Arneil G. Gabriel, Public Administration Department, Nueva Ecija University of Science and Technology. And Special thanks to Mr. Orlando C. De Leon and Mr. Reymo R. Aldama for allowing the researchers to conduct the survey in Department of Education - Division of Nueva Ecija.

\section{References}

Antiporda, J. (2018). 5 govt agencies probed for corruption. [Online] Available: https://www.manilatimes.net/5-govt-agencies-probed-for-corruption/400615/ (May 23, 2018).

Brillantes, A. B., \& Fernandez, M. T. (2011). Restoring Trust and Building Integrity in Government: Issues and Concerns in the Philippines and Areas for Reform. International Public Management Review, 55-79.

Calleja, M. T., Hechanova, M. R., Alampay, R. B., Canoy, N. A., Franco, E. P., \& Alampay, E. A. (2016). Transformation in the Philippine local government. Local Government Studies.

Caren, M. D. (2012). Spoils System in Philippine Bureaucracy: The Assassin of Political Neutrality.

Civil Service Commission. (2014). Report Card Survey. [Online] Available: http://www.csc.gov.ph/2014-02-21-08-16-56/2014-02-21-08-17-48/2014-02-28-06-38-42

Development Academy of the Philippines. Change is Here: Key Gains from the Philippine Results-Based Performance Management System. [Online] Available: https://www.dap.edu.ph/coe-psp/activities/change-is-here-key-gains-from-the-philippine-resu lts-based-performance-management-system/ (2018, February 1).

Gabriel A. G., \& Ong, D, U. (2018) Linking Transparency and Accountability to Local Legislative Performance in the Province of Nueva Ecija in the Philippines. Journal of Public Administration and Governance, 8(2), p.384.

Gabriel, A. G. (2017). Transparency and accountability in local government: levels of commitment of municipal councilors in Bongabon in the Philippines, Asia Pacific Journal of Public Administration, 39(3), 217-223. https://doi.org/10.1080/23276665.2017.136890210.1080/23276665.2017.1368902

Gabriel, A. G. (2018). Bureaucratic Red Tape in the Philippines. Springer Nature Switzerland.

Gabriel, A. G., \& Gutierrez, M. P. (2017). Praxis in Local Legislative Governance: Measure of Organizational Effectiveness of the Component Cities in Nueva Ecija, Philippines. Asia Pacific Journal of Multidisciplinary Research, 5(2).

GAN Business Anti-corruption Portal, (2017). The Philippines Corruption Report. [Online] Available: https://www.business-anti-corruption.com/country-profiles/the-philippines/ 


\section{Macrothink}

Journal of Public Administration and Governance ISSN 2161-7104 2019, Vol. 9, No. 1

Hays, J. (2008). Corruption in the Philippines. [Online] Available: http://factsanddetails.com/southeast-asia/Philippines/sub5_6f/entry-3906.html

Makati Business Club (2016) Improving the Citizen Experience: How the Anti-Red Tape Act is shaping public service delivery in the Philippines. Makati City Philippines

Tumampus, J. P. R., Romero, M. J. J., Espinoza, M. A. P., \& Cuya-Antonio, O. C. (2018) Factors Influencing the Quality of Health Care Provisions on Local Government Units. International Journal of Research and Innovation in Social Science, Volume II, Issue VIII, August 2018, ISSN 2454-6186, 1-5.

World Bank (2018). Doing Business 2018 Reforming to Create Jobs. Washington DC.

\section{Copyright Disclaimer}

Copyright for this article is retained by the author(s), with first publication rights granted to the journal.

This is an open-access article distributed under the terms and conditions of the Creative Commons Attribution license (http://creativecommons.org/licenses/by/4.0/). 